\title{
THE ROLE OF IS IN THE ACQUISITION OF FINITENESS BY ADULT TURKISH LEARNERS OF DUTCH
}

\author{
Ineke van de Craats \\ Radboud University Nijmegen
}

\begin{abstract}
This article deals with the interlanguage of adult second language (L2) learners acquiring finiteness. Due to the inaccessibility of bound inflectional morphology, learners use free morphology to mark a syntactic relationship as well as person and number features separately from the thematic verb, expressed by a pattern like the man is go. Results from longitudinally collected production data of Turkish learners of Dutch are reported and present evidence for the claim that (a) verb movement and production of inflectional morphology develop separately in various developmental steps and (b) finite forms in nonfinite contexts (and vice versa) are by-products of this development. Moreover, all is-patterns in different Germanic languages can be explained by the application of minimalist theory of verb movement and recent views on morphology. Is-patterns that correspond neither to the first language nor to the L2-a poverty-of-the-stimulus problem - turn out to be possible in other languages of the world and are constrained by Universal Grammar.
\end{abstract}

This article focuses on a striking, systematic pattern in the acquisition of finiteness by adult Turkish learners of Dutch, in which both syntactic position and morphological form play a decisive role. The pattern is intriguing because it exists neither in Turkish nor in Dutch and is related to verb movement. In this pattern, the verb form is -at first glance, the third person singular form of the

This study was supported by a grant (No.355-70-17) from the Netherlands Organization for Scientific Research.The author would like to thank Roeland van Hout and Theo Bongaerts for discussions as well as five anonymous SSLA reviewers for their valuable suggestions.

Address correspondence to: Ineke van de Craats, Department of Linguistics, Radboud University Nijmegen, PO Box 9103,6500 HD Nijmegen,The Netherlands; e-mail: I.v.d.Craats@let.ru.nl. 
copula zijn "to be" - and a thematic verb, either in an infinitival or an inflected form, are combined in a sentence, as in (1)-(3), taken from the Dutch part of the European Science Foundation (ESF) corpus (Perdue, 1993) and produced by one of the Turkish adults learning Dutch in a naturalistic setting. ${ }^{1}$ The pattern with an infinitival form (nonf) will be called the basic is-pattern, as it is the most frequent one; the pattern with an inflected form will be called the inflected ispattern. There are also utterances in which is occurs twice, as illustrated in (3).

(1) Basic is-pattern

Hij is lopen (Target: Hij loopt)

he is walk-NONF

"He walks"

(2) Inflected is-pattern

Hij is liegt (Target: Hij liegt)

he is lie-3SG-PRES

"He lies"

(3) Double is-pattern

Dan is die man is komt hier (Target:Dan komt die man hier)

then is that man is come-3sG-PREs here

"Then the man comes here"

Such utterances occur not only in the spoken production data of the Turkish uninstructed second language (L2) learners with a low level of education in the ESF corpus (see Starren, 2001) but also, in the present study, in the production data of Turkish adults, also with low levels of education, learning Dutch in an instructed classroom setting. It will be argued that these is-patterns are precursors of verb movement, not only in the acquisition of Dutch but also in other Germanic languages. Moreover, various accounts will be presented as well as a new account based on a minimalist copy and deletion approach.

\section{BACKGROUND}

\section{Is-Patterns in L2 Dutch}

The Dutch part of the ESF corpus (Perdue, 1993) comprises a large number of utterances with is-patterns. Before the is-patterns emerged, during the first 9 months of the project (Cycle 1), the two Turkish learners primarily produced long verb forms that cannot be discerned from infinitives, as in (4). ${ }^{2}$

(4) Typical long form

Dan mens brief lezen (Target:Dan leest de man de brief)

then man letter read-NONF

"Then the man reads the letter" 
In Cycle 2 (the second 9 months), the is-pattern emerged. Only the most advanced learner, Ergün, produced is-patterns: $35 \%$ in Cycle 2 and $42 \%$ in Cycle 3, including twice as many long forms as short forms (see Starren,2001). It turns out to be difficult to determine the meaning of the element is. Starren argued that the double is in (3) comprises two different functions depending on its position before or after the first noun phrase (NP) - that is, the subject.In her view, presubject is marks a topical element, whereas postsubject is marks an aspectual element. Starren based her argument on the structure of earlier developmental stages in which lexical elements in the same positions express tense and aspect. This is illustrated in (5a), in which the first element, gisterenjaar "yesterday year," has the topical function of anchoring the utterance on the time axis. The adverb altijd "always" expresses the aspectual function. In (5b), the postsubject is occurs in the position of the aspectual adverb. This is may have two different aspectual meanings: durativity and completion. Which aspectual meaning it expresses needs to be inferred from the context, although the context of (5b) is ambiguous in this respect. Example (5c) illustrates Starren's conclusion that presubject is as a topic marker (cf. Zobl, 2002, for is by Japanese learners of English) encodes the topic time and that postsubject is - as an aspectual marker-encodes the perfect aspect (and is, in that function, the precursor of an aspectual auxiliary).

(5) Topic-subject-aspectual marker word order

a. Gisteren-jaar ik altijd ongeluk maken yesterday-year I always accident make (Target: Vorig jaar had ik altijd ongelukken)

"Last year I always made accidents"

b. Dan hij is lopen (Target:Dan is hij gelopen)

then he is walk

"Then he walks"

c. Dan is die man is komt hier (Target:Dan is die man hier gekomen)

then is that man is come-3sg here

"Then that man has come here"

\section{Is-Pattern in L2 German}

Haberzettl (2003) came across the ist-pattern (equivalent to the Dutch is-pattern) in the data of Turkish schoolchildren learning German in an immersion setting. In free conversations and picture story-tellings, Haberzettl found both the basic ist-pattern and the inflected ist-pattern, the former emerging first. Examples from her data are given in (6a) and (6b).

(6) a. Basic ist-pattern

Eine Junge ist die Fussball spielen (Target: Ein Jungen spielt Fussball)

a boy is the football play

"A boy is playing football" 
b. Inflected ist-pattern

Quack ist nicht Geld kommt [= bekommt $]^{3}$

Quack is not money gets

(Target: Quack bekommt kein Geld)

"Quack does not get money"

Haberzettl listed all of the utterances of one learner consisting of a verb and at least one additional complement. Her data show the emergence and decline of the ist-pattern, which appeared between a subject (S)object (O)-verb (V) stage with uninflected verbs and a SVO stage with inflected verbs. The highest number of ist-patterns that occurred in her data was $41 \%$.

Haberzettl (2003) argued that the is-patterns she found differ from the patterns in Starren and van Hout (1997) and Starren (2001) in two respects: (a) She did not find utterances with two so-called proto-auxiliaries and (b) the interpretation of ist to express either an imperfective or a perfect aspect fits in many cases but not in all. In her view, it is problematic that (a) finite verb forms that express ongoingness also occur and (b) ist is also found in combination with a past participle without a perfect aspect, as in (7). However, this is also the case in Starren and Starren and van Hout:Is-patterns co-occur with short forms and past participles.

(7) Der ist so gemacht (Target: Er macht so)

he is so done

"He does like this"

As the ist-pattern is not the result of the learners' encoding of specific functional markings, Haberzettl argued that ist is to be viewed as the linking element between frequently used chunks. She referred to the cut-and-paste technique of a 2-year-old child learning first language (L1) English (see Tomasello, 2000, for details) and termed this strategy for L2 learners "tinkering with chunks" (p.57).

\section{Is-Patterns in L2 English}

Spontaneous Learner in the ESF Corpus. Ravinder, a learner of English with a Punjabi language background, produced all of the types of is-patterns, including the double is (cf.Huebner, 1989; Huebner, Carroll, \& Perdue, 1992). ${ }^{4}$ Huebner distinguished three utterance types in which is occurs: with transitive verbs (8a), with intransitive verbs (8b), and in utterances consisting of an adjective (Adj), a noun (N), or a prepositional phrase (PP) as in (8c) combined with is (i.e., in a copula construction). The three sentences in (8a) are instances of, respectively, the basic, the inflected, and the double is-pattern, (8b) is also an instance of the basic is-pattern, and (8c) is an instance of a copula construction. 
(is) $\mathrm{NP}_{1}$ (is) $\mathrm{V} \mathrm{NP}_{2}$ (PP) word order

a. Transitive verbs

i) Is looking bill

ii) Is Charlie said to girl

iii) Then is girl is push the policeman

(Huebner, p. 122)

b. Intransitive verbs

Cake man is again go to police

c. Predicative construction (is followed by an Adj, a NP, or a PP)

Is too much

(Huebner, p. 122)

Huebner (1989) distinguished utterances with transitive verbs from those with intransitive verbs because he assumed that is in Ravinder's data is an expression of viewpoint. He argued that because viewpoint perspective is expressed in Punjabi (an aspectual split-ergative language with both ergative-absolutive and nominative-accusative case marking) by agreement marking of the verb either with the patient (absolutive) or the agent (nominative), this L2 learner tried to find an equivalent of viewpoint expression by means of is. According to Huebner, is has a referring function, as shown in (9a): NP plus is and is plus NP are mainly used to reintroduce the main character, but, in Cycle 3, is plus NP, as illustrated in (9b), has a consistent function-to signal a new viewpoint.

(9) a. Is (= Charlie and the girl) talking and looking

(Target: They are talking and looking)

b. Then is (I think) wife and husband (Target: There's a wife and husband)

c. Is husband go to (er work) (Target: There's the husband going to work)

Huebner also observed cases with both prenominal and postnominal is, which he considered to be more problematic. Those are cases viewed in the present article as double is-patterns.

The is-patterns occur with increasing frequency in Ravinder's data: $13 \%$ in Cycle 1,23\% in Cycle 2, and 32\% in Cycle 3 (Huebner, 1989; Huebner et al., 1992). This increasing number of is-patterns is similar to what was seen in Ergün's data (up to $42 \%$ in Cycle 3). Huebner concluded that this growth is caused by Ravinder's developing system of viewpoint marking. The number of is-patterns is comparable to that observed for Haberzettl's (2003) informant (41\% in the ninth interview). For the adult learners Ergün and Ravinder, a decrease and complete disappearance of the is-pattern is not at issue.

Spanish Learners of L2 English. Fleta (2003) not only noted that insertions of $i s$ have been found in the interlanguage of child learners of English with different language backgrounds (French, Russian, and Bantu) but also found basic is-patterns in her own longitudinal data of Spanish children learning English in an immersion school. ${ }^{5}$ The data were obtained in semispontaneous story-tellings and role-playing. This yielded many basic ispatterns, as in (10a), in which is follows the subject. To know whether child L2 learners also use verb movement in yes/no questions, Fleta carried out a 
cross-sectional study: She induced primary school children to produce interrogatives, as in (10b) and (10c), in which is appears after as well as before the subject. This shows the first steps of subject-auxiliary inversion in English.
a. The zebras is eat grass
"Zebras eat grass"
b. The frog is have head?
"Does the frog have a head?"
c. Is he can jump?
"Can he jump?"

She concluded that is-insertion becomes systematic in a specific interlanguage stage just before targetlike mastery of verb movement.

Fleta (2003) did not compute the percentage of is-patterns with regard to inflected and uninflected thematic verbs so a quantitative comparison with the data of Starren (2001), Huebner (1989), and Haberzettl (2003) is not possible. Instead, she provided a morphosyntactic account for this phenomenon, claiming that her child L2 learners found is-insertion more economical than movement of the thematic verb. In other words, it is easier to insert a suppletive form is than to inflect a thematic verb or to invert the subject and the auxiliary.

Hawkins (2001) provided a syntactic account, taking examples from earlier research and claiming that is or do are the markers of a new functional projection, the complementizer phrase (CP), for a learner who indicates a question. Japanese learners of English (Zobl, 2002) produced is when acquiring agreement. This indicates the acquisition of a new projection agreement phrase (AgrP) — not found in Japanese — that seems to function as a topic marker.

Is-Patterns in L1 English and Dutch. The insertion of be forms into English interrogative sentences, as illustrated in (10c), is not restricted to L2 learners. It is also found in children acquiring their L1 (Radford, 1990; Roeper, 1992). According to Roeper, these is-insertions do not express modality, tense, or agreement but precede syntactic categorization and are produced as dummies to identify the functional category complementizer (C) during a short stage of acquisition. Hence, is-insertion is similar to do-insertion.

Whereas in English do-insertion is obligatory in negative and interrogative sentences, in Dutch the insertion of doen "to do" belongs to the substandard variety and appears in L1 acquisition as well. However, in child L1 Dutch, forms of zijn "to be" are rare. According to Blom (2003), it is not clear whether is in kindje is spelen-NONF "child is play" is a dummy or a precursor of the prepositional infinitival construction het kindje is aan het spelen translated as either "the child is on the play" or "the child is playing." Jolink (2005) claimed that, during a short period, children use is plus infinitive as the aspectual counterpart of zijn "to be" plus past participle: The former construction refers to uncompleted events; the latter refers to completed ones. This is very similar to the basic is-patterns of adult L2 learners. 


\section{Proposing a Morphosyntactic Account of Is-Patterns}

It has been shown that there is no agreement on the account of the three types of $i s$-patterns. Whereas some researchers focused on finding a functional or semantic account of is-patterns (Huebner, 1989; Starren,2001), others (Haberzettl, 2003) cast doubt on a semantic account. For that matter, a semantic account alone is not adequate without explaining how is is integrated in a syntactic structure. Zobl (2002) and Hawkins (2001) provided a syntactic account in which they related one of the is-patterns to the activation of a new AgrP or CP projection. However, they did not have the number and variety of $i s$-patterns that Fleta (2003) reported and that have been found in the present study.

The emergence of is-patterns is not an isolated phenomenon but should be viewed as part of the acquisition of verb placement. This issue has been dealt with in particular with regard to German, but it is also relevant for Dutch, as its syntactic structure is very similar to German. Researchers like Clahsen and Muysken (1986, 1989), Clahsen (1988), and Meisel $(1991,1997)$ have argued that whereas $\mathrm{V}$ movement and agreement seem to be linked together in L1 acquisition, finiteness and verb placement seem to be unrelated in SLA. Meisel (1991), for instance, found that infinitives and bare stems occur in positions in which inflected verb forms were expected and that finite (f) forms are found in nonfinite positions.

Here, it is claimed that all is-patterns can be accounted for through the adoption of a minimalist theory of verb movement and recent views on morphology. This leads to the following two hypotheses:

1. Verb movement and production of free (instead of bound) inflectional morphology develop separately in several developmental steps.

2. Is-patterns, nonfinite forms in finite contexts, and finite forms in nonfinite contexts are by-products of this development.

Morphology Separated from Syntax. In the last few years, considerable attention has been paid to the variability of inflectional morphology expressing agreement and tense. This variability manifests itself in spontaneous production and is pervasive during the course of acquisition. This is in contrast with the development of syntax, which seems to be successful (e.g., Haznedar \& Schwartz, 1997; Lardiere, 1998a, 1998b; Prévost \& White, 2000). Haznedar and Schwartz and Prévost and White argued for the missing surface inflection hypothesis. Lardiere (1998a, 1998b, 2000) claimed that mapping or interface problems between syntax and morphology are involved: The morphological component has problems reading the grammatical features (e.g., Halle \& Marantz, 1993). Mismatches may occur between abstract morphosyntactic properties (formal features) and their associated surface forms (phonological matrixes) as in (11a) for a verb form and (11b) for a nominal form. In (11a), the phonological matrix /blijven/ is raised out of the 
verb phrase (VP) and maps onto the formal features of third person singular. Similar infinitival forms occurring in a finite context have been observed by Lardiere, Haznedar and Schwartz, Prévost and White, and others. In (11b), the phonological matrix /jongens/ maps onto a singular feature (there is only one boy visible in the picture). This is due to morphological inability.

$\begin{array}{ll}\text { a. Mismatched verb form } & \\ \begin{array}{l}\text { Phonological matrix } \\ \text { Semantics }\end{array} & \text { /blijven/ } \\ \begin{array}{l}\text { Formal features } \\ \text { Target }\end{array} & \text { [3sG] } \\ \text { Relevant utterance } & \text { *Vader blijft daar } \\ & \text { * "Father blijven daar } \\ \text { b. Mismatched nominal form there" } & \\ \text { Phonological matrix } & \text { /jongens/ } \\ \text { Semantics } & \text { [boy-PLUR] } \\ \text { Formal features } & \text { [3sG] } \\ \text { Target } & \text { De jongens slapen } \\ \text { Relevant utterance } & \text { *De jongens slaapt } \\ & \text { *The boys sleeps" }\end{array}$

Minimalist Copy and Deletion Approach. In the Minimalist Program (Chomsky, 1995), a clear distinction is made between syntax as the structure building component and the lexicon from which lexical items are selected before being inserted in syntactic positions that share the features of the lexical item selected. This involves that, for instance, a verb with person, number, and tense features and with the corresponding morphemes is directly inserted underV (within VP) and is moved to the appropriate functional head for feature checking only later in the derivation. The lexical content is moved as well, together with the grammatical features: This results in the movement of the entire verb. Strong movement can be seen as a copying operation of formal features that moves the phonological matrix to a higher functional head. After copying, only a trace is left, and the original content is deleted. In some cases, however, the trace is not (completely) deleted. This results in doubling constructions in which a subject or a question word is doubled (Barbiers, 2006, for Dutch; Fanselow \& Cavar, 2002, for German). ${ }^{6}$ More variation is possible: Copying can be optionally partial—only selected features are copied-(Chomsky), or deletion can be optionally partial—not all features that have been copied are deleted-(cf. Fanselow \& Cavar; Nunes, 2005). Partial copying is also an option in Dutch and Flemish dialects (Barbiers); for instance, verb doubling, as in (12), where the light verb doen "to do" and the thematic verb afwassen "to wash the dishes" express together what is done by one finite verb form in standard Dutch. The features [1SG] and [PRES] are copied to a higher functional head and spelled out on the light verb (doen "to do"); other features are not copied. 
(12) Ik doe de kopjes afwassen
I do-PREs-1SG the cups off-wash-NONF
"I wash the cups"

Because the copying process occurs from right to left in the lexical string, or upward in the syntactic tree, partial copying involves that a less specified lexical item always precedes a more specified one or results in the underspecification of the higher element in the chain, as features that do not belong to the original feature bundle cannot be copied. Thus, the inverse of the is-patterns presented in (1)-(3), in which the thematic verb precedes is, cannot occur.

In the SLA of Dutch, the contrary may be found, as illustrated in (13a) and (13b), in which the verb form (krijg "get-1SG" and doet "do-3SG") is more specified than the trace, an infinitival form. However, for a learner, krijgen "get-NONF" bears the same features as krijg "get-1SG"; only the surface form differs. Thus, krijgen "get-NONF" is a default form with which Turkish learners start the learning of verbs. Hence, (13a) and (13b) are cases of full copying in which the phonological matrixes differ due to morphological inability.
a. Ik krijg jiet sociale
dienst geld krijgen $_{\boldsymbol{j}}$
I get-1sG not social-services department money get-NONF
(Target: Ik krijg geen geld van de sociale dienst)
"I don't get money from the social services department"
b. Die jongen $\boldsymbol{d o e t}_{\boldsymbol{j}}$ dicht doen $_{\boldsymbol{j}} \quad$ (Target:De jongen doet dicht)
that boy do-3SG closed doe-NONF
"The boy closes the door"

This may imply that a learner's variant with a nontarget surface form is inserted in syntax before movement. Notwithstanding this mismatch, the syntactic structure can be built up and a wrong surface form can be copied to a higher position, as shown in (13a) and (13b).

The Role of the L1. The L1 plays a role in multiple ways. In the first place, the L1 structure seems to be the reason why Turkish learners of Dutch acquire different elements from the environmental input than, for example, Moroccan learners. Both groups consider the Dutch input from a L1 viewpoint and expect to find the thematic verb at a different position in the sentence:Turkish learners (with SOV basic word order) at the end of the clause and Moroccan learners (with SVO or VSO basic word orders) at the first, second, or third position in the sentence (when they adjoin an adverbial element). As learners may find thematic verbs in both positions, Turkish learners will mainly acquire infinitives (e.g., komen "to come") and Moroccan learners will mainly acquire inflected forms (e.g., $k o m(t)-1,2,3 \mathrm{sG}$ "come(s)" or komen-PLUR "come"). Both language groups map different phonological matrixes onto the same feature bundle consisting of person, number, and tense features. Therefore, comparable to what Jansen, Lalleman, and Muysken (1981) claimed in their alternation hypothesis, it is assumed here that the L1 
is the reason why Turkish learners start with a default form that ends in -en and Moroccan learners with a default form that ends in $-t,-$ en, or with a stem. Only later will Turkish learners discover inflectional morphemes and Moroccan learners discover the infinitive. Therefore, such an assumption implies an indirect form of transfer for morphology and a direct form of transfer for syntax.

Turkish. Turkish (see Kornfilt, 1997) is traditionally considered to be a head-final language. The basic word order is SOV, although the word order appears rather free because subjects, objects, and adverbial adjuncts may follow the inflected verb. This postverbal position has the effect of backgrounding the information given and, as such, is a marked construction. When a subject follows the verb, it does not entail that the verb has been moved out of theVP but that the subject has been added to specify the empty position of the subject in specifier (Spec) AgrP.

Turkish is also an agglutinative language with rich inflectional morphology. Verbal suffixes can mark negation, modality, aspect, tense, and agreement.Additionally, it is a pro-drop language in which subject pronouns can be dropped under certain conditions. In this study, a head-final analysis of Turkish is adopted, as illustrated in (14).The verbal complex with all morphological material included is base-generated in $\mathrm{V}$.

(14) Syntactic structure of the Turkish clause

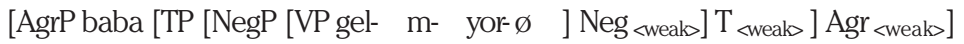
father come-NEG-PRES-3SG

"Father does not come"

The various grammatical features are subsequently checked in the relevant functional heads, but these features are weak and do not entail overt movement of the verbal complex; the functional heads are phonetically empty. A copula is not compulsory in present tense sentences and does not occur at the beginning of the sentence directly following the subject.

Dutch. Dutch has two possible word orders: $\mathrm{SV}_{\mathrm{f}} \mathrm{O}$ or S-Auxiliary (Aux)$\mathrm{OV}_{\text {nonf }}$ in the main clause and SOV(Aux) in the subordinate clause (Den Besten, 1989).Prepositional adjuncts may follow the sentence-final verb, as in Turkish, but subjects and objects may not. Verbal suffixes mark tense and agreement but not negation: Negation, aspect, and modality are expressed independently. In (15), a Dutch main clause with a separable verb, terugkomen "to come back," illustrates verb movement from V to Agr to C, in which komt "comes" is raised, whereas the particle terug "back" remains in situ.Unlike in Turkish, the inflected verb is moved to the second position in the main sentence (due to strong feature specifications of functional heads), and a long-distance split may occur between the auxiliary or modal and the thematic verb remaining in the VP, as illustrated in (16). When, in an embedded clause, $\mathrm{C}$ is filled by a complementizer, the finite form remains in sentencefinal position, as shown in (17). 
(15) Syntactic structure of the Dutch matrix clause

[CP vader [C' komtj [AgrP [TP [NegP niet [VP terug $t \mathrm{j}] \mathrm{Neg}<$ strong $>t \mathrm{j}$ ] father comes not back

$\left.\mathrm{T}_{<\text {strong }>} t \mathrm{j}\right]$ Agr $<$ strong> $\left.t \mathrm{j}\right]$ ]]

"Father does not come back"

(16) With a modal

Vader kan niet terugkomen

father can not back-come-NONF

"Father cannot come back"

(17) In an embedded clause

$\ldots$ [CP dat [AgrP vader [TP $\left.\left[\mathrm{V} t_{\mathrm{i}}\right] t_{\mathrm{i}}\right]$ terugkomt $\left.\mathrm{i}_{\mathrm{i}}\right]$ ]

"... that father comes back"

The verb zijn "to be" has two functions: It may be a copula or an auxiliary. When it is a copula, as in (18a), it is located in the head of Agr between the subject and a nominal or prepositional predicate. When it is an auxiliary, as in (18b), it occurs between the subject and the thematic verb (in VP). In (18c), an is-pattern is provided for comparison. In Dutch, most verbs select the auxiliary hebben "to have," but unaccusatives and ergatives select the auxiliary zijn "to be."

a. Copula

De vrouw is oud

"The women is old"

b. Auxiliary

De vrouw is gekomen

"The women has come"

c. Is-pattern

*Zij is naar de zee kijken / /kijkt (Target:Zij kijkt naar de zee)

She is at the sea look-NONF/look-3SG

"She is watching the sea"

The verb zijn "to be" has suppletive forms for first, second, and third person singular (ben, bent, is), whereas inflection of lexical verbs is marked by a zero morpheme (or stem) for first person singular and by $-t$ for second and third person singular. Plural forms are identical to the infinitive.

\section{THE STUDY}

\section{Data Collection and Participants}

This analysis is based on longitudinal data of five Turkish learners. These participants were selected from a larger corpus that consisted of eight learners' semispontaneous and experimental data, the low-educated L2 and literacy acquisition (LESLLA) corpus, because they showed more development of 
verb placement than the other learners. The five informants, 19-37 years of age, had received 5 years of education at a primary school in their native country and had been learning Dutch at a center for adult education for 7-18 months when the data collection began. The teaching method can be best characterized as reflecting a communicative approach. Some participants also profited from an immersion situation at work or from contact with Dutch neighbors, other mothers, and authorities. At the start of data collection, they were all beginners below the first level of the common European framework (Council of Europe, 2001), although some of them had been living in the Netherlands for 10 years or more when they started with the course.They had all mastered a basic vocabulary.

\section{Elicitation Tasks}

The data were collected over a period of $15-18$ months and were divided into three cycles of 5-6 months. In each cycle, the same tasks were administered, ranging from open-ended (film retellings, picture story-telling), to more controlled (sentence completion), and strictly controlled tasks (oral sentence imitation). The purpose of these experiments was to determine whether learners were completely unaware of specific basic morphosyntactic aspects or whether errors were made due to the stress or cognitive load of a spontaneous speaking task.

The basic tasks reported here are two production tasks: Task 1 was a film retelling task, Father and Daughter (Jennings, Thijssen, \& Dudok de Wit, 2000), and Task 2 was a picture story-telling task, The Snowman (Briggs, 1978). Some relevant items from two supplementary tasks not designed for triggering ispatterns were also used.The first of the two supplementary tasks was an oral sentence imitation task with three sentences containing an embedded clause in which $\mathrm{C}$ is phonologically realized through the complementizer dat "that." 7 In one of those sentences, ik geloof niet [ ${ }_{\mathrm{CP}} \boldsymbol{d a t}$ Hamid ziek is] "I don't believe that Hamid is ill," the complementizer was so difficult to perceive that the learners had to rely on their interlanguage grammar, which made it a good test of knowledge of complementizer use (providing evidence for the $\mathrm{CP}$ projection).The second supplementary task, sentence completion, was used for the selection of the participants in this study. Participants were asked to react to an oral stimulus while looking at the computer screen that showed a picture of (a) a man repairing a car and (b) a child reading a book. The oral stimulus was Wat doet deze man / jongen? Hassan / Osman... "What does this man / boy do?," the correct answers were Hassan maakt / repareert een auto "Hassan repairs a car" and Osman leest een boek "Osman reads a book," without explicitly expressing ongoingness, which is usual in Dutch. ${ }^{8}$ Because the participants had to react quickly, their answers were taken to reflect the current state of their grammatical knowledge. Three learners who used the 
dummy verb form is "is" or doet "does" (comparable light verb form) in their immediate answers were selected. Additionally, two learners were selected because they produced a low number of $i s$-patterns in the retelling tasks (see Table 1).

\section{RESULTS}

\section{Quantitative Overview of the Is-Patterns}

The answer patterns provided in Table 1 show that all five learners produced a sentence with the thematic verb in sentence-final position,transferred from their L1. More advanced learners make use of a more sentence-initial finite dummy form (i.e., is "is," doet "does"), with the thematic verb remaining in sentence-final position. This seems to signal that the is-pattern is to be considered a developmental step in using sentence-initial verb forms. ${ }^{9}$

For these five learners, all samples were scanned for verb-final sentences (generally with long forms), verb-initial sentences (generally with short forms in first, second, or third position of the sentence), and is-patterns. Copulas and modals are not taken into account in Table 2 to enable a comparison with Starren (2001) and Haberzettl (2003), who did not include modals and copulas.Table 2 shows that all learners use is-patterns, but the extent to which this pattern is used differs. The percentage of is-patterns found in two of the participants' data, Hülya and Zilfi, is most comparable to what was found for Ergün (a maximum of $42 \%$ ) investigated by Starren, for the child (41\%) reported by Haberzettl, and for the Punjabi learner of English (an increasing number of is-patterns up to $32 \%$ ) observed by Huebner (1989). In Table 2, the percentages are provided by cycle. When, however, the number of is-patterns is computed for each task, Zilfi has a score of $45 \%$ of $i s$-patterns in Task 1 of Cycle 1 and Hülya has a 51\% score in Task 2 of Cycle 3. This emphasizes the overall decrease of is-patterns for Zilfi and the increase for Hülya. As illustrated in Table 2, for Zilfi the decrease of is-patterns is accompanied by an increase of sentence-initial verbs.

This is also the case for Hilal, who produced fewer is-patterns than Hülya and Zilfi, with a maximum of $7 \%$ at the end of the data collection but who showed a greater increase in sentence-initial verbs. It seems that for Hilal the is-pattern has done its work as a trigger for movement of thematic verbs: The is-pattern may disappear in Hilal's production, as was observed in Haberzettl's (2003) child learner.This sequential effect is not found in Hülya's data because the number of is-patterns is still increasing in the last cycle of data collection.Yet, the emergence of is-patterns in Cycle 2 has had an effect on the number of sentence-initial verbs: Hülya replaces sentence-initial verbs with is-patterns.

Ayfer, the fourth participant, does not show any progress from Cycle 1 to Cycle 2. From Cycle 2 to Cycle 3, more is-patterns are produced and fewer 


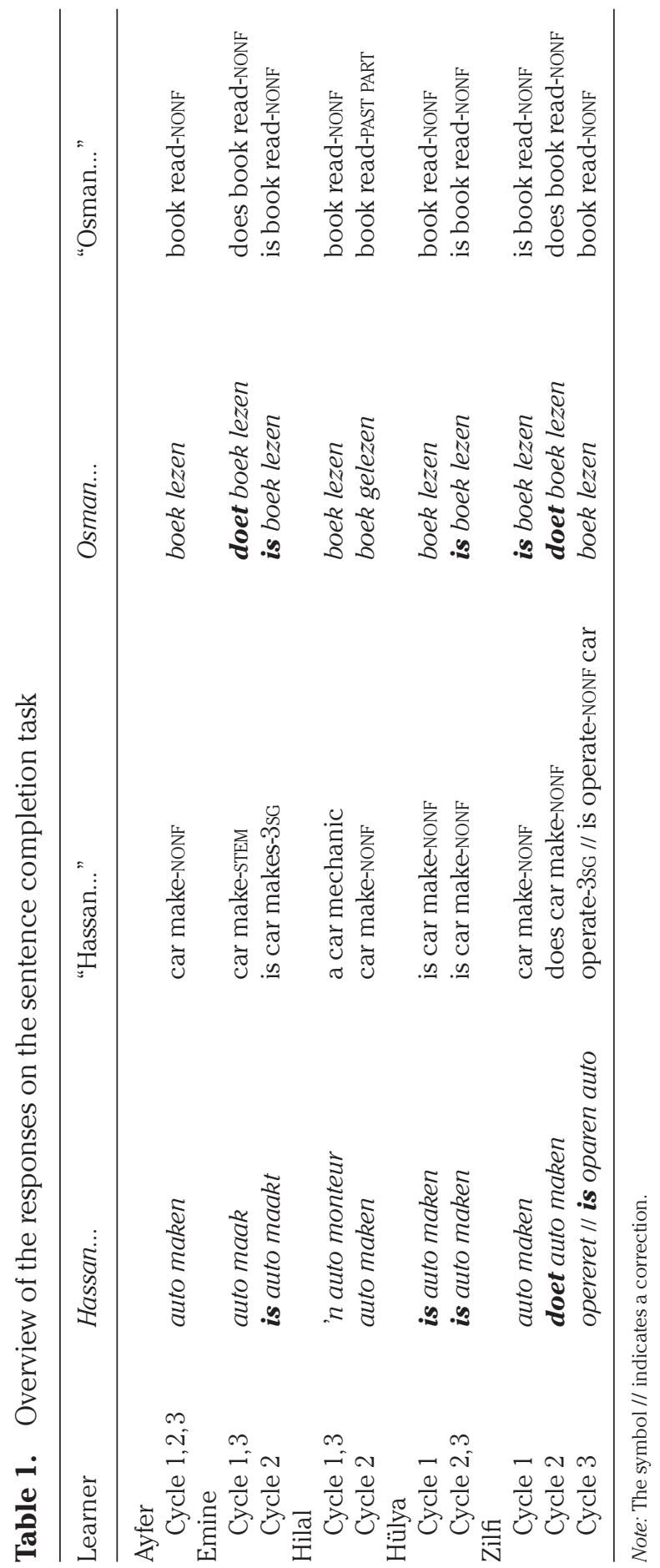


verb-final sentences are produced. The fifth participant, Emine, on the other hand, shows the opposite: Fewer is-patterns co-occur with more verb-final sentences, which points to regression after Cycle 1. Regression is very plausible, as she stopped attending lessons during the course of the project due to pregnancy.

Overall, with the exception of Emine, Table 2 shows (a) a decrease over time of transfer from L1 Turkish (i.e., fewer sentence-final verbs), (b) an increase and subsequent decrease of is-patterns, and (c) an increasing number of verbs at the beginning of the sentence. These developments point to a systematic shift from L1-based structures with sentence-final verbs to a more targetlike sentence organization with verbs in the first part of the sentence.

If transfer is assumed to be at the L2-initial state, progress can be considered from two perspectives: the extent to which a learner deviates from the L1 grammar and the extent to which a learner approximates the L2 grammar. This allows the description of distinct interlanguage grammars that may occur in between the L1 and the L2. For instance, the is-pattern intervenes and also determines the extent to which a learner progresses. From the L1 perspective, the learner with the most verb-final sentences is the least advanced. This implies that Ayfer in Cycle 1 (94\%) and Emine in Cycle 3 (90\%) are the least advanced learners and that Zilfi in Cycle 3 (55\%) is the most advanced. Emine turns out to have a regression (79\%, 83\%, and $90 \%$ of verb-final sentences in Cycles 1-3, respectively). From the L2 perspective, the number of targetlike verb-initial sentences is the main criterion. This means that Emine is the most advanced learner in Cycle 1, with 16\% of verb-initial sentences, but Hilal (31\%) and Zilfi (21\%) have the most targetlike verb placement sentences at the end of data collection. Emine shows the same regression effect, but now with respect to targetlike verb-initial sentences. The is-pattern seems to be a transitional construction between verb-final and verb-initial sentence constructions.

\section{Morphosyntactic Analysis of the Is-Patterns}

The Basic is-Pattern. Hülya's answers on the car stimulus in the sentence completion task are repeated in (19). The answers in Cycles 1-3 have the same meaning, and it is less plausible that only the answers in Cycles 2 and 3 , provided in (19b), express ongoingness, whereas the answer provided in Cycle 1 (19a) does not.

(19) NP is $\mathrm{OV}_{\text {nonf }}$ word order
a. Hassan auto maken-NONF (Target: Hassan maakt de auto) Hassan car repair
b. Hassan is auto maken-NONF (Target:Hassan maakt de auto)
"Hassan repairs the car" 
Table 2. Overview of the three main sentence types in both production tasks

\begin{tabular}{|c|c|c|c|c|c|c|c|}
\hline \multirow[b]{2}{*}{ Learner } & \multicolumn{2}{|c|}{ V sentence-final } & \multicolumn{2}{|c|}{ Is-pattern } & \multicolumn{2}{|c|}{ V sentence-initial } & \multirow{2}{*}{$\frac{\text { Total }}{N}$} \\
\hline & $N$ & $\%$ & $N$ & $\%$ & $N$ & $\%$ & \\
\hline \multicolumn{8}{|l|}{ Ayfer } \\
\hline Cycle 1 & 148 & 94 & 2 & 1 & 7 & 5 & 157 \\
\hline Cycle 2 & 183 & 96 & 0 & 0 & 8 & 4 & 191 \\
\hline Cycle 3 & 154 & 89 & 8 & 5 & 10 & 6 & 172 \\
\hline \multicolumn{8}{|l|}{ Emine } \\
\hline Cycle 1 & 94 & 79 & 6 & 5 & 19 & 16 & 119 \\
\hline Cycle 2 & 96 & 83 & 2 & 2 & 17 & 15 & 115 \\
\hline Cycle 3 & 86 & 90 & 1 & 1 & 9 & 9 & 96 \\
\hline \multicolumn{8}{|l|}{ Hilal } \\
\hline Cycle 1 & 123 & 87 & 4 & 3 & 14 & 10 & 141 \\
\hline Cycle 2 & 127 & 77 & 10 & 6 & 29 & 17 & 166 \\
\hline Cycle 3 & 93 & 62 & 9 & 7 & 47 & 31 & 149 \\
\hline \multicolumn{8}{|l|}{ Hülya } \\
\hline Cycle 1 & 102 & 89 & 1 & 1 & 12 & 10 & 115 \\
\hline Cycle 2 & 73 & 84 & 12 & 14 & 2 & 2 & 87 \\
\hline Cycle 3 & 45 & 58 & 27 & 35 & 5 & 7 & 77 \\
\hline \multicolumn{8}{|l|}{ Zilfi } \\
\hline Cycle 1 & 68 & 60 & 37 & 33 & 8 & 7 & 113 \\
\hline Cycle 2 & 69 & 59 & 31 & 26 & 18 & 15 & 118 \\
\hline Cycle 3 & 87 & 55 & 39 & 24 & 34 & 21 & 160 \\
\hline
\end{tabular}

Note: Modals, copulas, and past participles are not included.

The basic is-pattern appears first and is the most frequent of the three ispatterns. Three stages can be distinguished: After an acquisition stage of only bare VPs, is seems to act as a free functional morpheme. The results in Table 2 for Zilfi show that this is-pattern decreases over time and may completely disappear at the end, similar to Haberzettl's (2003) observations of the Turkish child. In none of the five Turkish adults examined here has the is-pattern fully disappeared at the end of data collection, except perhaps for Emine, who produced only one is-pattern in Cycle 3. However, the almost complete absence of is-patterns in her data reflects regression rather than progress. Finite verb forms with a bound morpheme increase in number, but is-patterns still occur. The question arises as to what the syntactic status of is may be.Consider the examples in (20), taken from Ayfer, in which (20a) was produced in Cycle 2 and (20b) was produced in Cycle 3.

(20) NP is Neg V word order
a. Vader niet komen-NONF (Target: Vader komt niet) father not come
b. Papa is niet komen-NONF (Target: Vader komt niet)
"Father doesn't come" 
Whereas the examples in (19) show that the syntactic position of maken "make" is sentence-final-because it follows the object-and suggest that the position of is must be higher than VP and lower than Spec AgrP, the example in (20b) is even more precise in showing that is must be higher than the negation phrase (NegP) and lower than Spec AgrP (i.e., in the head of AgrP). This development from infinitive (20a) to is plus infinitive (20b) implies a considerable syntactic change. As argued here, it is likely that, for Turkish learners in the early developmental stage, the infinitive has tense, person, and number features. So vader komen "father comes" becomes the Dutch equivalent of baba geliyor "father comes," whereas the target sentence is vader komt "father comes." The fact that the sentential negator in (20b) is not a bound morpheme as in Turkish but rather a free functional morpheme seems to be acquired very early. This is important evidence that L2 learners can easily develop free functional morphemes. The negator niet "not" is basegenerated in the Spec NegP position, whereas the head is phonetically empty, as in Turkish, and probably head-final like the other functional heads represented in (21).

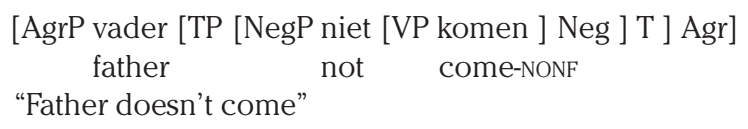

The sentence Ayfer builds in Cycle 3 (20b) is an important step forward compared to (20a), as she has discovered that the functional head Agr can be phonetically filled and that AgrP can be a head-initial projection. This implies that, in principle, she can produce targetlike constructions with verb-initial sentences. Note that this structure is not fully fledged Dutch because there is no V-to-C movement, resulting in verb second (V2) constructions, which are completely lacking at this stage. ${ }^{10}$ The syntactic structure of (20b) is represented in (22).

(22) Syntactic structure of a basic is-pattern

[AgrP vader [Agr' is [TP [NegP niet [VP komen ] Neg ] T] Agr]]

father is not come-NONF

"Father doesn't come"

The question arises as to why is, as a possible spell-out of person and number features, would be introduced if the verb already has such features. When a learner has understood that the function of the copula is to carry agreement features (and at a later stage also tense features) and is able to generate a copula, is emerges also in sentences in which the thematic verb should overtly carry those features in the form of a bound morpheme. Similar to the expression of the sentential negator (a bound morpheme in the L1) by a free functional morpheme (niet "not") in the L2, the bound agreement morpheme can now be seen expressed as the free morpheme is. This learner has thus 
developed an interlanguage grammar in which agreement needs to be expressed separately from the thematic verb in the first part of the sentence. From a theoretical perspective, a Turkish learner has begun to acquire a movement operation that consists of a syntactic and a morphological component, operationalized in (23) and (24), respectively.

(23) The syntactic component

A new syntactic relationship has to be acquired: In L1 Turkish, this relationship was characterized as weak; in the L2, it is a strong relationship that entails visible movement, from $\mathrm{V}$ —via Tense (T)—to Agr.

(24) The morphological component

The learner has to become aware of the fact that the infinitive does not match the target form and that overt morphology is lacking.

For all five Turkish learners, the acquisition of this movement operation turns out to be a long process that takes place in a series of fine-grained alternating syntactic and morphological developmental steps. The first step is the emergence of the basic is-pattern. As is is often underspecified for number and tense (cf.de ouders is niet slapen "the parents do not sleep"), it may be assumed to be the marker of a structural relationship. In other words, is is not moved to the Agr position as an independent verb generated within the VP but rather inserted as the spell-out of one (or more) features of the thematic verb that are copied to Agr.

The Inflected is-Pattern. The inflected is-pattern is characterized by is plus a visibly inflected form, hij is liegt "he lies." It is important to know that Turkish learners produce more basic than inflected is-patterns and produce them earlier as well.These conclusions can be inferred from the data presented in Table 3. Another conclusion to be drawn from Table 3 is that is plus infinitive is gradually replaced by is plus a (visibly) inflected form: This points to morphological development. As sentences with a negator, as shown in (25), provide more syntactic cues, negators are used to demonstrate how Zilfi deals with the phases of the overt movement operation: partial copying in (25a) and (25b), produced in Cycle 1 and Cycle 2, respectively, and complete copying and deletion in (25c) and (25d), produced in Cycle 3.

Table 3. Overview of the distribution of the types of $i s$-patterns

\begin{tabular}{lcccr}
\hline Learner & Basic is-pattern & Inflected is-pattern & Double is-pattern & Total \\
\hline Ayfer & 8 (Cycles 1,3) & 1 (Cycle 3) & 1 (Cycle 3) & 10 \\
Emine & 6 (Cycles 1,2,3) & 3 (Cycles 1,2) & - & 9 \\
Hilal & 20 (Cycles 1,2,3) & 2 (Cycles 1,2) & 1 (Cycle 3) & 23 \\
Hülya & 38 (Cycles $1,2,3)$ & 2 (Cycle 3) & - & 40 \\
Zilfi & 78 (Cycles $1,2,3)$ & 19 (Cycles 1,2,3) & 10 (Cycles 1,2,3) & 107 \\
\hline
\end{tabular}


(25) Target: Vader komt niet

a. Papa is niet komen daddy is not come-NONF

b. Papa is niet kom daddy is not come-1sG

c. Mijn vader kom $_{\mathrm{j}} \quad$ terug $t_{\mathrm{j}}$ my father come-1sG back

d. $K_{\mathrm{j}} \mathrm{m}_{\mathrm{j}}$ niet $t_{\mathrm{j}}$ die vader come-1sG not that father

"Father does not come"

In (25a), the first stage of development is shown:The relationship is marked by an inserted is in the head of AgrP-this is primarily a syntactic operation. In (25b), the morphological aspect develops in situ:The thematic verb is visibly marked for singular (the stem). The next step is again a syntactic one: In (25c) and (25d), the underspecified surface form of the thematic verb is moved upward; there is no visible trace left within the VP.All features of the entire feature bundle plus the surface form have been cut (i.e., copied and deleted) and pasted (i.e., spelled out, except for the third person feature $-t$, as this feature has yet to be acquired). The last step in this development will be morphological—that is, getting the correct form komt-3sG "comes," which raises to the head of AgrP.

Let us turn to the occurrence of is with an inflected form. Does the movement of the thematic verb entail the immediate deletion of the is-form that created the landing position for the movement operation? The pattern of acquisition turns out to be more fine-grained than expected. In (26), it can be seen how the inflected form has raised and adjoined to the head of AgP, whereas is has not yet been deleted or incorporated in the thematic finite verb form (ligt "lies").

(26) Zij is ligt in de boot $\left.{ }_{\mathrm{vP}} t_{\mathrm{j}}\right]$ (Target:Zij ligt in de boot)

she is lies in the boat

"She is lying in the boat"

The development in (25) and (26) occurred over 15 months. Because Zilfi progressed slowly, these two examples show the alternation between syntactic and morphological steps in great detail. At this point in the developmental process, the target structure has not yet been attained because the finite verb should raise to $\mathrm{C}$ in order to make $\mathrm{V} 2$ possible.

This stepwise acquisition pattern appears to match the regression effect observed for Emine.The instances in (27) represent relevant data from the three cycles. The utterances from Cycle 1 illustrate all of the possible VPinternal morphological variations for a verb like komen "to come." The first utterance of Cycle 2 (misschien vader komt "maybe father comes") may be an instance of a finite verb in the head of AgrP, but because there is no negator or any adverbial element between the subject and the verb, 
it is impossible to decide on the exact position of the verb. The remaining examples of Cycle 2 (27b) are clear instances of a VP-internal verb. As illustrated in (27c), the examples in Cycle 3 are similar to those in Cycle 1 (27a). The regressive pattern fits, in reverse order, the progressive pattern found for the other four learners.

(27) Development of the verb komen "to come"

a. Cycle 1

i Papa niet komen I kom I I komt (Target:Papa komt niet)

Papa not come-NONF / come-STEM /come-3sG

ii Papa is niet komt (Target: Papa komt niet)

Papa is not come-3SG

b. Cycle 2

i. Misschien vader komt (Target:Misschien komt vader)

Maybe father come-3sG

ii. Dochter is ook weer komen (Target: De dochter komt ook weer)

Daughter is again come-NONF

iii. Niet komen vader (Target: Vader komt niet)

Not come-NONF father

c. Cycle 3

i. Vader niet komen / komt (Target:Vader komt niet)

Father not come-NONF / come-3sG

"Father does not come"

The Double is-Pattern: A Second Movement. It has been demonstrated that strong movement (from V to Inflection [I] or Agr) occurs in two steps: a syntactic one and a morphological one, or a partial copy before a full copy. Here, it will be shown that a copy of the dummy verb is can emerge even higher in the syntactic tree, between an adverbial adjunct and the subject. The latter is instantiates a second movement operation in the data. Thus, the double is-pattern can be explained as a combination of two developmental steps: movement from $\mathrm{V}$ to I and then from I to $\mathrm{C}$ (the latter movement is unfamiliar to learners with a Turkish L1 background). The first step has both a morphological and a syntactic component, and the second step involves a purely syntactic purpose: to achieve the V2 effect.

So far, the is-patterns were divided into two types depending on the morphological status of the thematic verb: nonfinite or finite. Another division can be made depending on the position of $i s$ before or after the subject, following Starren (2001) and Huebner (1989). The problem for such a division is that Turkish allows subject drop, and, as an effect of transfer, this is also observed in the Dutch interlanguage of Turkish learners. Therefore, there are many cases in which is is linked to a nonfinite verb or a finite one, whereas the subject is lacking. Such cases are inconclusive for the syntactic analysis to decide whether the position of is precedes or follows the subject, as shown in (28). The adverb nu "now" is not decisive 
either because it can be (a) an adjunction to AgrP as in (28b) or (b) an adverbial in Spec CP as in (28c).

(28) Target: Nu stopt ze met fietsen

a. Inconclusive pre- or postsubject is $\mathrm{Nu}$ is stoppen fietsen now is stop cycle-NONF

b. Postsubject is [AgrP nu [AgrP pro is [VP stoppen fietsen]]]

c. Presubject is [CP nu is [AgrP pro [VP stoppen fietsen]]] "She stops cycling now"

In the utterances produced by Ayfer provided in (29a), in which is precedes the subject papa "father," it is obvious that the position of the first is is in the head of CP, as represented in (29b). The functional heads C and Agr have become phrase-initial instead of phrase-final.

(29) Target: Vader komt niet

a. Is papa is niet komen is father is not come-NONF

b. [C' is [AgrP papa is [NegP niet [VP komen]]]]

"Father doesn't come"

For Ayfer, the example in (29) is, unfortunately, the only clear case of presubject is. Hülya showed one instantiation of presubject is, which is not a part of the double is-pattern at the same time. The position of komt "come" is not clear-cut; it may also be within the VP,as illustrated schematically in (30).

(30) Wanneer is vader komt (Target: Wanneer komt vader?)

[CP wanneer [C' is [AgrP vader komt $\left.\left.\left[\mathrm{VP} t_{\mathrm{i}}\right]\right]\right]$ ] when is father come-3sG

"When does father come?"

Although not all is-patterns with a presubject is are preceded by an adverbial of time, $50 \%$ of them are introduced in this way. The adjunction of an adverbial seems to lead to the insertion of $i s$ between the adverbial and the subject in C. ${ }^{11}$ Only Zilfi produced a considerable number of $i s-N P-V$ patterns that increased over the three cycles-double is-patterns included. A similar tendency to start with an adverbial of time can be observed for the is-patterns with a phonetically empty pro; these are used by Zilfi, as shown in Table 4. Without an overt subject, however, it is not possible to determine where is has been inserted. From a developmental perspective, this stage can be considered a transition between the postsubject and presubject is-pattern. Table 4 gives an overview of the is-patterns with regard to the position of is vis-à-vis the subject, if present; the number of double is-patterns is not indicated 
Table 4. Position of is in is-patterns

\begin{tabular}{lccc}
\hline Learner & Postsubject & $\begin{array}{c}\text { With phonetically } \\
\text { empty pro }\end{array}$ & Presubject \\
\hline Ayfer & & 1 & 0 \\
Cycle 1 & 1 & 0 & 0 \\
Cycle 2 & 0 & 6 & 1 \\
Cycle 3 & 2 & 1 & 0 \\
Emine & & 0 & 0 \\
Cycle 1 & 5 & 0 & 0 \\
Cycle 2 & 2 & 3 & 0 \\
Cycle 3 & 1 & 3 & 0 \\
Hilal & & 0 & 0 \\
Cycle 1 & 1 & & 0 \\
Cycle 2 & 7 & 1 & 0 \\
Cycle 3 & 10 & 0 & 1 \\
Hülya & & 0 & 9 \\
Cycle 1 & 0 & & 6 \\
Cycle 2 & 12 & 26 & 12 \\
Cycle 3 & 26 & 18 & \\
Zilf & & 19 & \\
Cycle 1 & 9 & & \\
Cycle 2 & 7 & & \\
Cycle 3 & 8 & & \\
\hline
\end{tabular}

Note: The number of is-positions is higher than the number of is-patterns for learners producing double is-patterns.

separately but has been integrated into the data. From Table 4, it can be inferred that (a) the emergence of is-patterns may be considered a sign of progress, (b) the postsubject is emerges before the presubject is, (c) Zilfi is the most advanced learner, using the CP projection, and (d) Emine stagnates and regresses. Zilfi does not seem to respect this order of emergence at first, but, in her data, the number of postsubject patterns is already decreasing in favor of finite forms and an increasing number of presubject patterns. In Cycle 3, Zilfi even starts to express the past tense in situ. The CP projection and the verb form is play a role in that process, as shown in (31).

(31) Toen is ze klein was (Target: Toen was ze klein)

then is she little was

"At that time she was a little girl"

As illustrated in (31), the past tense is marked by the adverb toen "then" and by was "was" at the end of the clause. The only aspect that is not yet targetlike is that the verbal form was "was" has not raised. Even V2 has been applied by the spell-out of the features in C, resulting in a VS word order because the clause is introduced by an adverbial. 
It has become clear that, in the learners' data, there is a relationship between Agr and C, on the one hand, and the basic realization of features under these heads: is - a kind of default verb without conceptual content-on the other hand.In a Dutch matrix sentence, $\mathrm{C}$ dominates the inflected verb, but, in a subordinate clause, $\mathrm{C}$ dominates the complementizer. The complementizer with the least semantic content in Dutch is dat "that," as illustrated in (32). If there is a relationship between the activation of the $\mathrm{CP}$ projection and the realization of presubject is, there should also be a relationship between the $\mathrm{CP}$ projection and the realization of the complementizer. ${ }^{12}$ The complementizer dat "that," for instance, will not be realized by a learner as long as there is no evidence of this projection in the matrix clause (e.g., by the production of $i s$ ). Therefore, it is expected that only L2 learners who use presubject is will produce the complementizer dat "that."

In the oral sentence imitation task, the five participants were asked to repeat the sentence illustrated in (32), in which the complementizer was difficult to perceive because it followed the stressed negator niet "not," requiring that the learners rely on their grammatical competence. The results on this specific item of the imitation task are rather clear-cut: In the first stage, the complementizer is omitted, as illustrated in (32b); in the next stage, the complementizer dat "that" is replaced by is (but only by those who can produce a presubject is-pattern), as in (32c), and only the most advanced learner, Zilfi, produces the complementizer, as shown in (32d).

(32) a. Stimulus

Ik geloof niet dat Hamid ziek is

I believe not that Hamid ill is

b. Stage 1

Ik geloof niet Hamid ziek is

c. Stage 2

Ik geloof niet is Hamid ziek is

d. Stage 3

Ik geloof niet dat Hamid ziek is

"I do not believe that Hamid is ill"

\section{The Developmental Course of Finiteness and the Role of the Is-Pattern}

The is-pattern in relation to the development of finiteness is examined here. Research questions to be considered are the following:

1. What is the structure of the sentence before the appearance of $i s$ ?

2. How do other verb forms like copulas, modals, and auxiliaries develop, and what is their relation to the is-pattern? 
3. What consequences does the appearance of the is-pattern have for the thematic verb in the sentence?

For the classification in Tables 5 and 6, it is assumed that an uninflected verb is VP-internal, as long as there is no counterevidence. Through transfer from the L1, a sentence-final infinitive can be followed by a subject, an (indirect) object, or an adverbial adjunct. Nonthematic verbs like copulas and modals are considered to be base-generated in I, not moved to that position (cf. Ouhalla, 1991). Thematic verbs are analyzed as situated in Agr when they are inflected and followed by a complement, a sentential negator, or an adverbial adjunct. The morphological form may be a correctly inflected form, a stem, or an infinitive. If the syntactic position of the inflected verb cannot be determined because there are not enough phrases in the sentence, the verb was not included in Tables 5 and 6 . A double is-pattern is classified both under postsubject and presubject and not separately as a double is-pattern. Finally, a thematic verb is considered to be dominated by $\mathrm{C}$ only if it occurs in a presubject position, as in (33a) produced by Zilfi in Cycle 3. In (33b), this results in a targetlikeV2 construction produced by Zilfi in Cycle 2 .
a. Kijk $\quad$ kinderen nog een keer ${ }^{13}$ (Target: Het kind kijkt nog een keer) look-STEM children once again
"The child looks once again"
b. Zelf doet sneeuwman licht aan
self does snowman light on
(Target: De sneeuwman doet zelf het licht aan)
"The snowman switches the light on himself"

In Tables 5 and 6 , the data concerning the position of the verb are given in percentages. The production data of the two tasks (with an interval of 1 month) are separated to complete the developmental line of the informants as much as possible.

With regard to research question 1, the structure of the sentence before the emergence of the is-pattern, Tables 5 and 6 show that (a) the majority of the thematic verbs emerge first in a sentence-final position within the VP (more advanced learners have fewer VP-internal forms [e.g., Zilfi, Hülya, Hilal], and regression involves the production of more noninflectedVP-internal verb forms than were produced in earlier cycles [Emine]), and (b) a few thematic verbs appear in the head of Agr as inflected forms at the same early stage as the VPinternal verbs (i.e., Ayfer in all three cycles; Hülya in Cycle 1). There are no participants for whom is-patterns are completely lacking in the first sample, which suggests that is-patterns precede and co-occur with inflected verbs in Agr.The same verbs often occur in a later stage of development also in is-patterns (e.g., is linked to different morphological forms of komen "to come").

With regard to research question 2 , it has been observed that the underspecified copular form is emerges (in Agr) before (for Ayfer, Hilal, Hülya, and Zilfi) 
or at the same time as modals (for Emine). The underspecified copular form also appears at approximately the same time as the is-pattern as well as before real auxiliaries - most auxiliaries produced by the participants are is-patterns with participles, as can been seen in Tables 5 and 6. Moreover, it was found that copular forms occur more frequently than bare modals.

With regard to research question 3 , the effect of the appearance of $i s$ on the thematic verb can be observed most clearly in Hülya's data: An increase of copulas and is-patterns leads to a decrease in the number of early, inflected forms. In Cycle 2, Hülya seems to have replaced finite forms with is-patterns because finite forms are completely lacking in the sample from Task 2 . The finite forms slowly come back in Cycle 3 and occur along with many copulas and is-patterns. This may indicate a restructuring of her interlanguage: Finite verbs are now moved from the VP instead of being inserted directly in Agr.For Hilal, an increasing, but still relatively low, number of $i s$-patterns and copulas are produced together with a decreasing number of inflected verbs in Agr, until the sample from Task 2 in Cycle 2.In that sample, the number of thematic verbs that raise to Agr increases: Uninflected verb forms in Agr, as illustrated in (34), occur in 50\% of the cases in which an inflected form would be required. For Hilal, the is-patterns seem to have affected her word order much more than her verbal inflection; there is full copying of features that take along the incorrect phonological matrix (i.e., the infinitive).

De vader blijven daar lang in de zee

The father stay-NONF over-there long-time in the sea (Target: De vader blijft lang op zee)

"The father stays on the sea for a long time"

Zilfi shows a slowly decreasing number of is-patterns (in Agr, from 24\% in Cycle 1 to $14 \%$ at the end of data collection). She is the only participant who, at the end of data collection, has developed a substantial number of presubject is-patterns in C. After a stagnation in Cycle 2,Ayfer begins to produce more copulas and is-patterns. The Agr node gets activated and a modest number of inflected verbs appear in Cycle 3. Emine is able to use copulas, is-patterns, and inflected forms (first three samples) but falls back to an earlier developmental stage (copulas and is-patterns disappear, and the number of verb-final sentences increases).

One may wonder why is (as a part of the is-pattern) will emerge if a learner already has activated Agr, as shown by inflected verbs in that position (Hülya, for instance, used the inflected forms kijk "look" and maakt "makes" in Cycle 1 but is kijken "is look" and is maken "is make" in Cycle 2). The most plausible assumption is that learners cannot link the two separate positions of the verb in the L2 sentence and therefore create an intermediate solution, because they think that a finite thematic verb at the beginning of the sentence is wrong and that this position should be reserved for nonthematic verbs. Given the fact that modals never emerged before the copular form is and that is-patterns 


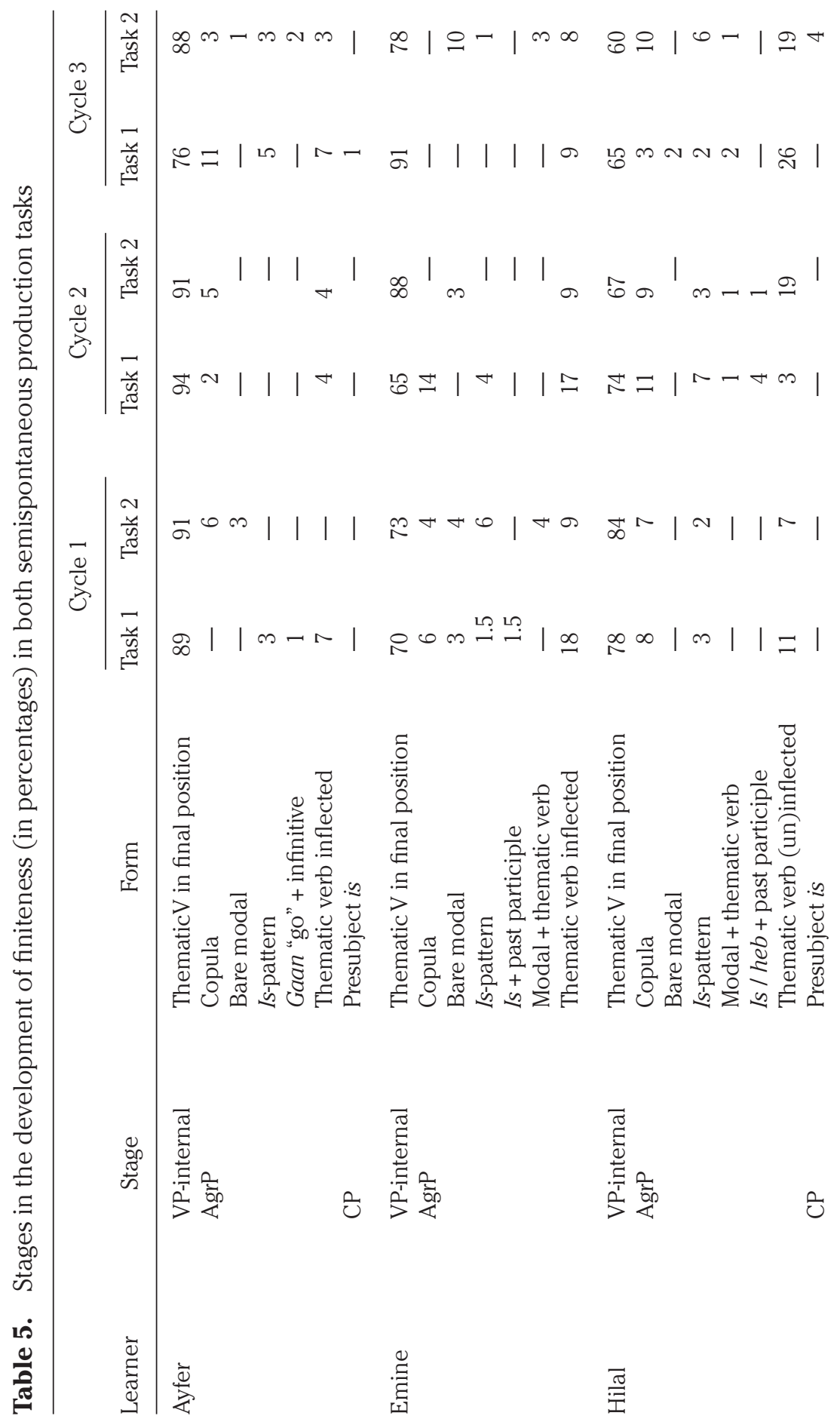




$$
\begin{aligned}
& \text { ลั่ } \\
& \text { ก๊ำ เ }
\end{aligned}
$$

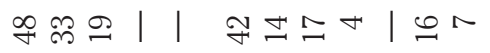

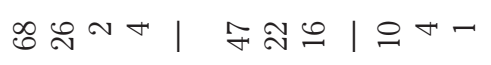

$$
\begin{aligned}
& \text { × }
\end{aligned}
$$

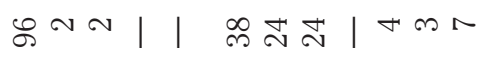

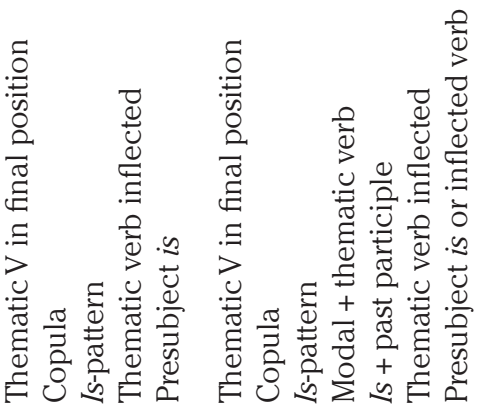

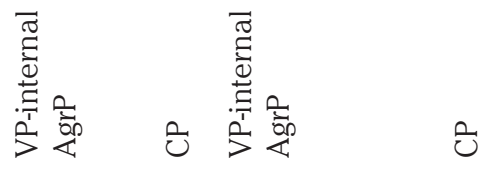

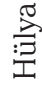

$$
\begin{aligned}
& \stackrel{\longleftarrow}{\doteqdot}
\end{aligned}
$$


Table 6. Total number of utterances with a verb form

\begin{tabular}{lcccccccr}
\hline & \multicolumn{2}{c}{ Cycle 1 } & & \multicolumn{2}{c}{ Cycle 2 } & & \multicolumn{2}{c}{ Cycle 3 } \\
\cline { 2 - 3 } Learner & Task 1 & Task 2 & & Task 1 & Task 2 & & Task 1 & Task 2 \\
\hline Ayfer & 69 & 99 & & 63 & 138 & & 93 & 99 \\
Emine & 65 & 77 & & 56 & 73 & & 32 & 78 \\
Hilal & 66 & 95 & & 90 & 134 & & 96 & 114 \\
Hülya & 57 & 65 & & 57 & 77 & & 55 & 80 \\
Zilfi & 79 & 91 & & 73 & 93 & & 100 & 117 \\
\hline
\end{tabular}

never emerged before modals, it is more likely that the copula is the trigger for the movement operation (see also Vainikka \& Young-Scholten, 1998). As the copula at the beginning of the sentence is salient and seems most appropriate-being a linking element without semantic content-to this group of learners, they start to overuse is and replace inflected thematic verbs with is plus infinitive (which entails the initial decrease of inflected verbs and the sparse use of modals plus infinitive).The most advanced Turkish learner,Zilfi, repeats this strategy for the activation of C: She copies the features of Agr on $\mathrm{C}$ and thus arrives at a V2 structure.

\section{CONCLUSIONS AND DISCUSSION}

The aim of this study was to provide a unified account for all is-patterns. It was claimed that-due to recent syntactic and morphological theories like the Minimalist Program and more particularly the copy and deletion approach as well as the separation of syntax and morphology-one morphosyntactic account can unite earlier explanations of $i s$-patterns. The focus of this study was on the data of five Turkish learners of Dutch, whose L2 development could be followed in great detail due to the longitudinal design and the fact that the learners acquired the new language slowly, as has been observed in many learners with only primary school education or less.

The data of the five Turkish learners support hypothesis 1: In adult SLA, free morphology replaces bound morphology at a stage of development preceding movement of the complete verb. Meisel's $(1991,1997)$ findings were also supported in the sense that verb movement and finiteness are not entirely related, as has been demonstrated in L1 acquisition. Inflectional morphology may emerge in the base position (VP-internally) but also later in the derivation. It also became manifest that is plays a role in both syntactic and morphological development. Is marks the relationship between two syntactic positions, either a weak (see Fleta, 2003, for data on L2 English) or a strong relationship (all other examples of movement to Agr or C). Is indicates the 
landing position of movement and may also be the copy and its spell-out form as a free morpheme of person and number features separate from the thematic verb. Schematically, the order of the morphological development of thematic verbs can be represented by the stepwise development of the sentence He writes a letter, as in Table 7. This schematic order supports hypothesis 2 that is-patterns, nonfinite forms in finite contexts, and finite forms in nonfinite contexts are by-products of this development. Moreover, the data have shown that there is little variability in this order of appearance:Although Ayfer's production generally exhibits patterns typical of theVP and AgrP stage (see Table 7), one of her utterances demonstrates the copy of features from Agr to $\mathrm{C}$, which is found in stage 7 .

The proposed morphosyntactic analysis of $i s$-patterns is also applicable to the data discussed by Starren (2001) and Haberzettl (2003): The order of the is-patterns, in V-to-I or I-to-C movement, is not reversed in any of their examples. Such an analysis would reject the copy and delete account. The same holds for the English data discussed by Huebner (1989), Zobl (2002), Fleta (2003), and Hawkins (2001, in which only presubject inflected is-patterns related to the syntactic position of $\mathrm{C}$ are discussed).Those examples show that, in English, to do is not the only dummy verb carrying person and number features; to be can also have this function, as suggested by Roeper (1999). Let us now turn to the explanation proposed by Huebner for the is-patterns in Ravinder's data.

Huebner (1989) provided an alternate analysis for the Punjabi learner of English. In Huebner's analysis, is figures in the nominal domain and has a pronominal character with a pragmatic function: that of focusing. In a bare position, is refers to persons mentioned before, is plus NP and NP plus is are mainly used to reintroduce the main character, and, in the last cycle, is signals a new viewpoint. Huebner's analysis does not seem plausible for several reasons. First, some L2 learners use the same postsubject is (e.g., the Turkish learners of Dutch and German; the Spanish learners of English in Fleta,2003), whereas other L2 learners of English produce the same presubject is as the Spanish learners reported by Hawkins (2001) and Fleta without referring to persons. Second, Huebner attributed different functions (i.e., reference function and viewpoint marking) to the copular form; these differ radically from the function in the target language. Huebner interpreted is in utterances as is looking to bill or is too much as a pronoun referring to Charlie and the bill Charlie has to pay, respectively. Similar utterances occurred in the data from the Turkish learners and were analyzed here as utterances with a null subject and a copula. Finally, Huebner could not explain the double is-pattern. The morphosyntactic account adopted here can straightforwardly explain presubject is-patterns such as is husband go to (er work) and double is-patterns such as then is girl is push the policeman. These utterances differ from the interrogative constructions reported by Hawkins and Fleta, in that there is no need for a CP projection in English. In target English, then would be adjoined to AgrP, but because a $\mathrm{CP}$ projection is necessary to generate interrogative 


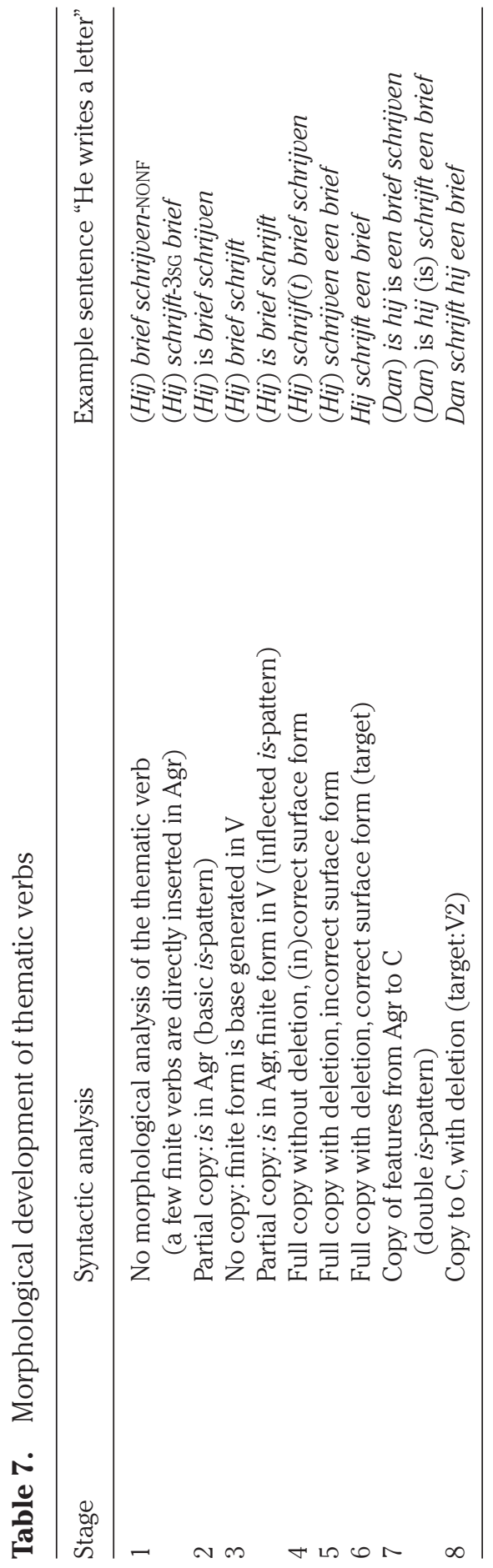


sentences, Huebner's Punjabi learner of English projects a CP and fills the head of CP with is instead. He even seems to do so when he wants to signal a new scene without using an adverbial as tense marker, as in is husband go to (er work) or is Charlie said to girl. Huebner's learner seems to overuse the $\mathrm{CP}$. (Recall that the Turkish learners showed the same tendency to use a temporal adverbial plus is in $50 \%$ of the cases.)

This brings us to the functional or semantic account of is-patterns proposed by Starren (2001). In her view, presubject is is primarily a topic marker that develops into a marker of tense, whereas postsubject is is an aspectual marker that expresses durativity or perfectivity. Before the emergence of the is-pattern, these functions are expressed by adverbial expressions. Although is may often express durativity or perfectivity in the ESF data produced by the Turkish speaker Ergün,such a reading is often less evident when watching the stimulus material, the silent movie Modern Times (Chaplin, 1936). Likewise, in Task 1, also a film retelling task, it is often hard to say whether an utterance like papa is niet komen means "father has not come" or "father does not come." If Starren's interpretation is right, one will expect a learner to say he has not come at a more advanced stage, but, in Cycle 2 , the same learner in the same task produced an inflected form in the position of the infinitive papa is niet kom-1SG "daddy is not come" in which a present tense with the inflected verb before the negator is produced.An auxiliary of tense was not provided, but Zilfi produced a finite verb in sentence-initial position when she said kom niet die vader "come-1SG not that father," contrary to Starren's predictions. In sum, the verb form is behaves more like an auxiliary carrying inflection than like an auxiliary of aspect. In the picture story-telling, many is-patterns are linked to thematic verbs without explicitly expressing durativity or perfect aspect. It can be concluded that there is no hard evidence in the data for a semantic motivation of the is-pattern.

The data of the five Turkish learners of Dutch provide insight into an intriguing interlanguage pattern. As verb movement and inflectional morphology are hard to apply, the learners resort to easier (more economical) devices such as insertion of is. The frequent copula form is in the target language provides them with a linking element between subject and predicate. Learners start using the copula with a nominal predicate and subsequently overuse it with a verbal predicate, which is ungrammatical in the target L2.Therefore, these learners use the copula inappropriately: They consider it to be a dummy, as a carrier of inflection for a thematic verb. This dummy becomes the vehicle to mark new or newly activated functional heads, such as Agr and C, and to meet agreement requirements, as shown by the data of the more advanced learners Zilfi and Hülya. At first, no motivation could be found in the data for this copy strategy other than a syntactic one: The newly activated projection must be licensed. There is no clear semantic motivation for this strategy. The interlanguage grammar itself is constrained by Universal Grammar (UG) because dummies or light verbs are used in many languages-as is the case in the relevant target languages 
discussed here-although not the verb to be. The inflected is-pattern is also a pattern governed by UG, as it occurs in languages that permit inflected modals and auxiliaries in combination with inflected thematic verbs, as in Moroccan Arabic (Harrell, 1962). The is-patterns, which both L1 and L2 learners of Germanic languages like Dutch, German, and English produce, point to a shared use of a UG-constrained pattern for the shared problems with verb movement.

(Received 23 January 2008)

\section{NOTES}

1. The ESF corpus is a large crosslinguistic and longitudinal corpus collected in five European countries. In each country, the L2 development of four adult learners from two different language backgrounds was investigated (see Perdue, 1993).Two Turkish and two Moroccan learners are represented in the Dutch part of this corpus.

2. The two Moroccan learners from the ESF corpus, however, primarily produced typical short forms, consisting of a stem or a stem plus - $t$ (inflection), as in die man pakt die meisje "the man catches the girl."

3. Haberzettl (2003) viewed kommt "comes" as a participle (Target:bekommen "got"); it can also be viewed as a third person singular of the present tense (Target: bekommt "gets"). In that case, it is an inflected is-pattern. 1992).

4. In Huebner (1989), is is represented as [iz] and viewed as a pronoun (Klein \& Perdue,

5. I am indebted to the anonymous SSLA reviewer who drew my attention to this article providing data very similar to mine.

6. An example of a doubly realized wh-word wie "who" (Barbiers, 2006) is provided in (i):

(i) Wie denk je [wie ik in de stad heb gezien]?

Who think you who I in the town have seen

"Who do you think I have seen downtown?"

7. A sentence imitation task can tap a participant's implicit knowledge of grammar. If a stimulus sentence contains a grammatical feature that has not been acquired, this feature will unconsciously be changed in such way that the sentence fits the participant's own grammar (see, e.g., Bley-Vroman \& Chaudron, 1994).

8. In Dutch, it is possible to express ongoingness with a prepositional infinitive construction, as in Hassan is een auto aan het maken "Hassan is repairing a car" (although this structure is more marked).

9. Here, the term verb-initial will be used for all sentences in which the verb appears in nonfinal position-that is, in first, second, or third position of the sentence: for instance, in a subject-less sentence (VO), in a sentence with subject (SVO), or in a sentence with subject and an adjoined adverbial before the subject (XSVO).

10. An adverbial element can be adjoined to AgrP, which results in a verb third order. Due to her lingering verb-final structural organization, Ayfer produces very few examples of this construction. One example is drie keren fietse vallen "the bike falls for the third time," in which the verb vallen "fall" is nonfinite.

11. Those adverbials are time markers like nou "now," toen "then," wanneer "when," and nog een keer "another time." Only Zilfi produced other types of adverbials.

12. Whereas most subordination in Turkish is essentially an embedded gerund that precedes the finite verb, there is also evidence of full clausal complements with a complementizer in the head of C (Kornfilt, 1997). There is no clear evidence, however, for the position of C: sentence-final (with the complementizer diye "that" or "because") or sentence-initial (with the complementizer $k i$ "that"). Clauses with left-headed $k i$ "that" are rather common in certain varieties of colloquial Turkish (Underhill, 1976).

13. Only one child is meant here. 


\section{REFERENCES}

Barbiers, S. (2006, July).Er zijn grenzen aan wat je kunt zeggen [There are limits to what one can say]. Inaugural lecture, Utrecht University, The Netherlands.

Bley-Vroman, R., \& Chaudron, C. (1994). Elicited imitation as a measure of second language competence. In E. Tarone, S.M. Gass, \& A.D. Cohen (Eds.), Research methodology in second language acquisition (pp.245-261). Mahwah, $\mathrm{NJ}$ : Erlbaum.

Blom, E. (2003). From root infinitives to finite sentence. Unpublished doctoral dissertation, Utrecht University, The Netherlands.

Briggs, R. (1978).De Sneeuwman [The Snowman]. Bussum:Van Holkema \& Warendorf.

Chomsky, N. (1995). The Minimalist Program. Cambridge, MA: MIT Press.

Clahsen, H. (1988). Parameterized grammatical theory and language acquisition: A study of the acquisition of verb placement and inflection by children and adults. In S. Flynn, G. Martohardjono, \& W.O'Neil (Eds.), The generative study of second language acquisition (pp.33-54). San Diego, CA:Academic Press.

Clahsen, H., \& Muysken, P.(1986).The availability of Universal Grammar to adult and child learners. Second Language Research, 2, 93-119.

Clahsen, H., \& Muysken, P.(1989).The UG paradox in L2 acquisition. Second Language Research, $5,1-29$.

Chaplin, C. (Producer/Writer/Director). (1936). Modern times [Motion picture]. United States: United Artists.

Council of Europe. (2001). A common European framework of reference for languages: Learning, teaching, assessment. New York: Cambridge University Press.

Den Besten, H. (1989). Studies in West Germanic syntax.Amsterdam: Rodopi.

Fanselow, G., \& Cavar, D. (2002). Distributed deletion. In A. Alexiadou (Ed.), Theoretical approaches to universals (pp.65-97). Amsterdam: Benjamins.

Fleta, M.T. (2003). Is-insertion in L2 grammars of English: A step forward between developmental stages? In J. M. Liceras, H. Zobl, \& H. Goodluck (Eds.), Proceedings of the 6th Generative Approaches to Second Language Acquisition Conference (pp. 85-96). Somerville, MA: Cascadilla Press.

Haberzettl, S. (2003). "Tinkering" with chunks: Form-oriented strategies and idiosyncratic utterance patterns without functional implications in the IL of Turkish speaking children learning German. In C. Dimroth \& M. Starren (Eds.), Information structure and the dynamics of language acquisition (pp.45-63). Amsterdam: Benjamins.

Halle, M., \& Marantz,A. (1993). Distributed morphology and the pieces of inflection. In K. Hale \& S. J. Keyser (Eds.), The view from building 20 (pp. 111-176). Cambridge, MA: MIT Press.

Harrell, R. S. (1962). A short reference grammar of Moroccan Arabic. Washington, DC: Georgetown University Press.

Hawkins, R. (2001). Second language syntax. Oxford: Blackwell.

Haznedar, B., \& Schwartz, B. D. (1997). Are there optional infinitives in child L2 acquisition? In E. Hughes, M. Hughes, \& A. Greenhill (Eds.), Proceedings of the 21st Annual Boston University Conference on Language Development (pp.257-268). Somerville, MA: Cascadilla Press.

Huebner, T. (1989). Establishing point of view: The development of coding mechanisms in a second language for the expression of cognitive and perceptual organization. Linguistics, 27, 111-143.

Huebner, T., Carroll, M., \& Perdue, C. (1992). The acquisition of English. In W. Klein \& C. Perdue (Eds.), Utterance structure: Developing grammars again (pp. 61-121). Amsterdam: Benjamins.

Jansen, B., Lalleman, J. A., \& Muysken, P. (1981). The alternation hypothesis: Acquisition of Dutch word order by Turkish and Moroccan foreign workers. Language Learning, 31, 315-336.

Jennings, C. (Producer), Thijssen, W. (Producer), \& Dudok de Wit, M. (Writer/Director). (2000). Father and daughter [Motion picture]. The Netherlands: CinéTé Filmproductie BV.

Jolink,A. (2005). Finite linking in normally developing Dutch children and children with specific language impairment.Zeitschrift für Literaturwissenschaft und Linguistik, 35, 61-80.

Klein,W., \& Perdue, C. (Eds.). (1992).Utterance structure: Developing grammars again.Amsterdam: Benjamins.

Kornfilt, J. (1997). Turkish. London: Routledge.

Lardiere, D. (1998a). Case and tense in the "fossilized" steady state. Second Language Research, 14, 1-26. 
Lardiere, D. (1998b). Dissociating syntax from morphology in a divergent end-state grammar. Second Language Research, 14, 359-375.

Lardiere, D. (2000). Mapping features to forms in second language acquisition. In J. Archibald (Ed.), Second language acquisition and linguistic theory (pp. 102-129). Oxford: Blackwell.

Meisel, J. M. (1991). Principles of Universal Grammar and strategies of language learning: Some similarities and differences between first and second language acquisition. In L. Eubank (Ed.), Point counterpoint: Universal Grammar in the second language (pp. 231-276). Amsterdam: Benjamins.

Meisel, J. M. (1997). The acquisition of the syntax of negation in French and German: Contrasting first and second language acquisition. Second Language Research, 13, 227-263.

Nunes, J. (2005). Linearization of chains and sideward movement. Cambridge, MA: MIT Press.

Ouhalla, J. (1991). Functional categories and parametric variation. London: Routledge.

Perdue, C. (1993). Adult language acquisition: Cross-linguistic perspectives. New York: Cambridge University Press.

Prévost, P., \& White, L. (2000). Missing surface inflection or impairment in second language acquisition? Evidence from tense and agreement. Second Language Research, 16, 103-133.

Radford,A. (1990). Syntactic theory and the acquisition of English syntax. Oxford: Blackwell.

Roeper, T. (1992). From the initial state to V2:Acquisition principles in action. In J. M. Meisel (Ed.), The acquisition of verb placement (pp.333-370). Dordrecht: Kluwer.

Roeper, T. (1999). Universal bilingualism. Bilingualism: Language and Cognition, 2, 169-186.

Starren, M.(2001). The second time:The acquisition of temporality in Dutch and French as a second language. Unpublished doctoral dissertation,Tilburg University,The Netherlands.

Starren, M., \& van Hout, R. (1997). Do temporal adverbials shape morpho-syntactic tense and aspect marking? In A. Sorace, C. Heycock, \& R. Shillock (Eds.), Proceedings of Generative Approaches to Language Acquisition '97 Conference on Language Acquisition (pp.456-461). Edinburgh: University of Edinburgh.

Tomasello, M. (2000). First steps towards a usage-based theory of language acquisition. Cognitive Linguistics, 11, 61-82.

Underhill, R. (1976). Turkish grammar. Cambridge, MA: MIT Press.

Vainikka, A., \& Young-Scholten, M. (1998). Morphosyntactic triggers in adult SLA. In M.-L. Beck (Ed.), Morphology and its interfaces in second language knowledge (pp. 89-113). Amsterdam: Benjamins.

Zobl, H. (2002). Multiple subject constructions in Japanese and the development of Agr in L2 English. In S. Foster-Cohen, T. Ruthenberg, \& M. L. Poschen (Eds.), Eurosla yearbook (Vol.2,pp. 29-47).Amsterdam: Benjamins. 